\title{
POLY ALKYL CYANOACRYLATE NANOPARTICLES AS DELIVERY VEHICLE IN COMBATING DISEASES
}

\section{Science \\ Ardhendu Kumar Mandal* \\ Central Instrumentation Division CSIR-Indian Institute of Chemical Biology, India*Corresponding Author}

\section{ABSTRACT}

The major problems in drug delivery to specific diseased sites possess drug-resistance, drug-toxicity, biological barriers and non-specificity to the target-cells observed among patients worldwide. To overcome these barriers, the biodegradable poly alkyl cyanoacrylate (PACA) nanocarriers have been used, while a core made up of PACA is functionalized with biologically active ligands such as cargos, biotin and antibody for enabling specific targeting, and stabilized with outer polyethylene glycol or surfactants in combating cancer, neurodegenerative and infectious diseases. The review demonstrates mainly the synthesis, functionalizations and the biomedical applications of PACA nanoparticles against various diseases to consider them as potent delivery vehicle.

\section{KEYWORDS}

Diseases; Poly alkyl cyanoacrylate nanoparticles; Functionalizations; Potent delivery vehicle

\begin{abstract}
Introduction
Many people suffer from severe diseases such as infectious, cancer or neurodegenerative disorders every year throughout the world [1-12]. The diseases generally develop when oxidative stress generated by toxicants dominates over the antioxidant defense mechanism and the protective innate and acquired immunity of the host body [13]. Infectious organisms generally survive in the host phagolysosomal compartment and spread throughout the host cells in the diseased state [14], while uncontrolled proliferation of cells without apoptotic cellular death make the disordered cells cancerous followed by in some instances metastasis. Alzheimer's disease (AD) represents the progressive productions and the toxic aggregations of $\beta$-amyloid peptides 1-42 (A $1-42)$ and the intracellular accumulations of the hyper-phosphorylated tau proteins in the brain neurons affecting acetyl-cholinestarase activity, while Parkinson's disease (PD) represents the deficits of dopaminergic neurons within the substantia nigra pars compacta and the dopamine decrement in the striatum accompanied with reactive oxygen species (ROS) generation.
\end{abstract}

In many of the cases, the conventional treatment of the diseases cannot cure the patients completely showing their aggravations of the disease state as drug resistance due to over-expressions of efflux proteins such as P-glycoproteins and multidrug resistant proteins, biological barriers such as blood brain barriers that restrict the exchange of solutes between the blood and the brain extra-cellular fluid where brain endothelial cells and peripheral endothelia are joined by tight junctions, systemic enzymatic drug degradations, non drug specificity to cells, drug toxicity, non drug-stability and non drug targeting efficiency become prominent. To overcome these obstacles, it is needed a delivery system to target cargos to specific site of interest for treating diseases having insignificant side effects. In this concern, nanotechnology, a multidisciplinary area, consists of engineering functional systems at the molecular level covering material science, applied physics, colloidal and interface sciences, and supra-molecular chemistry as well as electrical, mechanical and chemical engineering for the applications in the medical and pharmacological fields as nanoparticulated, nanomedicinal drug delivery. Therefore, the ideal nanomedicine platforms should represent their appropriate features such as (i) biodegradability / biocompatibility to permit secure administration, (ii) exhibition of stealth properties for escaping the immune responses, (iii) functionalizations with radioactive fluorescent probes to trace / localize them, and (iv) suitability for surface-functionalizations with ligands for achieving active targeting to specific cells. In this context, different polymers have been utilized to transfer active compounds to target sites for getting better therapeutic index as delivery vehicles, while biodegradable nanoparticles have been emphasized more for biomedical applications as they provide better encapsulation efficiency, longer bioavailability, sustained release and insignificant side toxicity.

Targeted treatments are utilized for blocking the specific biological transduction signaling or diseased proteins involved in for their progressive development i.e. the molecular targets such as growth factors, receptors, kinase cascades, and apoptotic and angiogenic molecules that are available in normal cells, but are mutated or over- expressed in diseased cells. The objective of these treatments is to occlude the signals that induce the malignant cells to expand and split frantically, and to create the diseased cells-deaths with the induction of apoptosis, stimulation of the immune system or targeting the delivery of cargos especially to diseased cells, diminishing normal cells-death and preventing the unwanted concomitant effects $[15,16]$. Active targeting is achieved with the attachment of distinct ligands to the nanoparticles-structures to allow a discriminating identification of various antigens or receptors over-expressed in the diseased cellssurfaces to increase the cytotoxic actions of the cargos with the insignificant side effects, as the exposures of cargos to healthy cells are minimized [17]. The functionalizations of the polymer nanoparticlessurfaces, not only provide their active targeting activities, but also improve the therapeutic efficacies of the cytotoxic active compounds to overcome also the multi drug resistance (MDR) $[18,19]$.

In this concern, biodegradable colloidal poly alkyl cyanoacrylate nanoparticles (PACA NPs) have attracted attention for nanobiomedical applications as they have exhibited their significant preclinical outcomes in several pathologies such as severe microbial infections and cancer as well as in few autoimmune and metabolic diseases [20-22]. Presently, in phase III clinical assessments, doxorubicin-stuffed PACA NPs have exhibited their upgraded safety and survival compared to the usual treatments in patients with MDRhepatocarcinomas [23], and their overlay with polyethylene glycol (PEG) not only turned them into long-circulating nano-vectors but also enabled them to traverse the blood-brain-barrier (BBB) [24-26]. To accomplish particular disease targeting, biotin and folic acid were used as ligands with PACA NPs to target selectively different cancer cell lines as receptors-mediated cancerous cells-uptake therapy [27-30]. For the treatment of AD, PACA NPs were functionalized either with drugs or with a distinct antibody through the biotin / streptavidin attachment to bind not only the cerebral A $\beta 1-42$ monomer, but also A $\beta 1-42$ fibrillar aggregates [27-29]. This review demonstrates the therapeutic efficacies of PACA NPs for the treatment of cancer, neurodegenerative disorders and microbial infections to consider as suitable delivery vehicle.

\section{Synthesis and preparation of poly alkyl cyanoacrylate nanocomposites}

Alkyl cyanoacrylate monomers are generally reactive highly owing to their combination of ester and nitrile electron-withdrawing groups bonded to the same carbon atom leading to polarization of the $C=C$ bond susceptible to be attacked by anions and compounds having nucleophilic groups such as amines.

Alkyl cyanoacrylate monomers are utilized for their anionic polymerization in water to synthesize polymers (Fig.1). The hydroxyl groups present in water initiate reaction by attacking on the extreme methylene group of the alkyl cyanoacrylate monomers. The resultant carbanions behave as nucleophiles and react with other alkyl cyanoacrylate monomers for producing the growth of carbanion chains resulting in the generation of PACA, while polymerization becomes ceased by mobile protons present in water. In general, $1 \mathrm{~mL}$ monomer is adjoined in one shot to $15 \mathrm{~mL}$ water to carry out 
polymerization for $1.30 \mathrm{~h}$ at $40^{\circ} \mathrm{C}$ under magnetic stirring at $1200 \mathrm{rpm}$. After that time, a milky suspension is acquired for the poly isohexyl cyanoacrylate (PIHCA) and poly butyl cyanoacrylate (PBCA). For the case of poly isobutyl cyanoacrylate (PIBCA), poly propyl cyanoacrylate (PPCA) and poly ethyl cyanoacrylate (PECA), a milky dissolution containing polymer-aggregates is obtained. The milky suspensions are freeze-dried whereas the aggregate polymers are liquefied in acetone, and dried under vacuum at room temperature. The polymers, thus derived, are utilized for the preparation of nanoparticlecomposites.

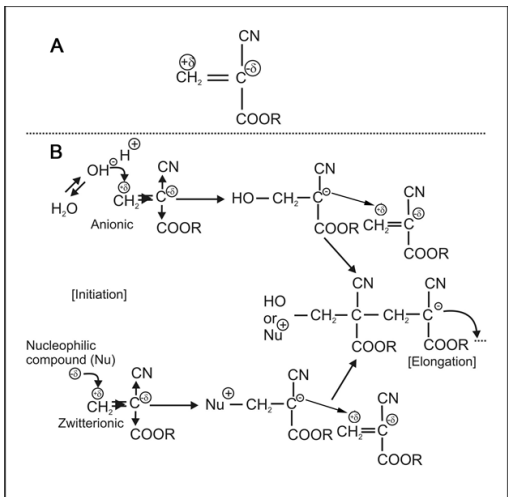

Fig.1. Chemical structure (A) and scheme of anionic and zwitterionic polymerization (B) of monomeric alkylcyanoacrylates.

For the preparation of nanoparticle-moieties (Fig.2) utilizing nanoprecipitation and emulsification-solvent evaporation modified methods [31,32], an organic solution (acetone) $(2 \mathrm{~mL})$ of PACA $(20$ $\mathrm{mg}$ or $10 \mathrm{mg})$ is mixed with drug $(2 \mathrm{mg})$ in acetone / chloroform $(0.5$ $\mathrm{mL})$. The mixture solution is then added drop-wise to an aqueous solution $(5 \mathrm{~mL})$ of surfactant such as $0.5-1 \% \mathrm{w} / \mathrm{v}$ pluronic F-68 / polysorbate 80 / poloxamer 188 or another stabilizer such as dextran 70,000 / poly ethylene glycol (PEG) in $0.001 \mathrm{~N} \mathrm{HCl}(\mathrm{pH} 1-2.5)$ under vigorous mechanical stirring $(1200 \mathrm{rpm})$ for $2.5-3 \mathrm{~h}$ at room temperature. The resultant dissolution is nullified with $0.1 \mathrm{~N}$ sodium hydroxide $(\mathrm{NaOH})$ solution to finish the polymerization reaction. The organic solution is then evaporated under reduced pressure and nanoparticles are purified by centrifugation and filtration. The final pellet is resuspended in deionized water to yield a nanoparticle suspension which is lyophilized after addition of 3\% mannitol as cryopreservative for future use

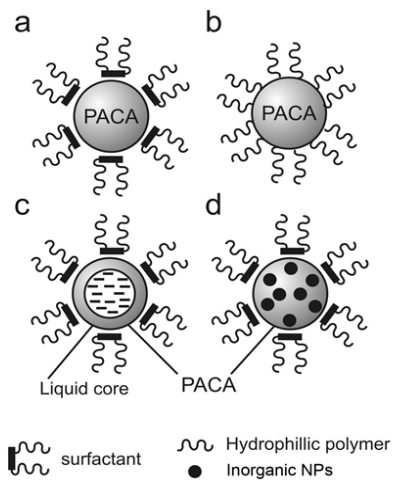

Fig.2. Schemetic presentation of various types of produced polyalkylcyanoacrylate nanoparticles.

For the preparation of nanocapsules composed of a liquid core with a surrounding polymeric envelope, interfacial polymerization techniques may be applied [33-38], while the reactions are accomplished either in microemulsions or in oil-in-water or in waterin-oil emulsion systems resulting in the creation of oil or water containing respective nanocapsules. To prepare oil-possessing nanocapsules by the polymerizations of alkyl cyanoacrylates at the oil/ water interface of oil-in-water emulsions, an organic phase containing $1 \mathrm{~mL}$ oil, $0.125 \mathrm{~mL}$ alkylcyanoacrylate, and drug liquefied in $25 \mathrm{~mL}$ acetone or ethanol is added into the $50 \mathrm{~mL}$ aqueous-phase containing $0.25 \%$ hydrophilic surfactant under strong magnetic stirring. The development of milky suspension implies the formation of nanocapsules, while an ideal $2 \%$ oil/ethanol ratio in the organic phase is maintained [38]. The organic solvent is then evaporated out and the residual suspension is ultracentrifuged to get pellet of nanocapsules. The aprotic solvents such as acetonitrile and acetone, and protic solvents such as ethanol, iso-propanol, n-butanol are used to induce the generation of nanocapsules and additional nanospheres with nanocapsules respectively. On the other hand, water-containing nanocapsules are prepared by the interfacial polymerizations of alkylcyanoacrylates in water-in-oil microemulsions. In this process, water-swollen micelles of uniform and small sized surfactants are disseminated in an organic phase. The monomers are then adjoined to the microemulsion where they may polymerize at the surface of the micelles to form polymers at the water-oil interface and may precipitate to yield the nanocapsule shells $[34,36,37]$. These watercontaining nanocapsules may encapsulate water-soluble molecules e.g. nucleic acids, antisense oligonucleotides and peptides [37,36], which are useful for the intravenous administration, as the aqueouscore-containing nanocapsules may be converted into an aqueous continuous phase by ultra-spinning of the oily dissolution over a layer of pure water possessing $\operatorname{Span} \circledast 80$ [36].

Poly alkyl cyanoacrylate nanospheres may also be prepared by emulsion polymerization method [39] used to synthesize colloids with a matrix structure of nanosphere (Fig.2). In this process, the polymerization is actuated by the hydroxyl ions of water, and then elongations of the polymer chains occur on the basis of anionic polymerization mechanism (Fig1) controlled in an aqueous medium by the adjustment of the $\mathrm{pH}$ with the concentration of the anionic polymerization inhibitor in the monomer and strong mineral acid [40]. In brief, $100 \mu \mathrm{L}$ monomer is dispersed in $10 \mathrm{~mL}$ acidified water $(\mathrm{pH}$ $2.5)$ containing a colloidal stabilizing agent or a surfactant $(0.5-1 \%$ pluronic $\mathrm{F} 68$ or dextran 70 ) to allow polymerization for 3 to $4 \mathrm{~h}$ under strong magnetic stirring, while drugs may be entrapped in PACA nanospheres or coupled covalently to the surfaces of nanospheres $[41,42]$.

\section{Characterizations of poly alkyl cyanoacrylate nanocomposites} Microscopic techniques such as Scanning Electron Microscopy, Transmission Electron Microscopy and Atomic Force Microscopy determine the morphology of the nanocomposites along with their size, distribution analysis and roughness of the material-surface. Dynamic Light Scattering is used to determine the size of the Brownian nanoparticles in colloid suspension along with zeta potential measurements as stability studies. Fourier Transform Infrared Spectroscopy is used to get information about the confirmative structural details of proteins such as their nature of modifications in folding, chemical bonding in lyophilized nanoparticle-suspension.

Poly alkyl cyanoacrylate nanoparticles as delivery carrier Few potential utilities of PACA NPs as drug delivery device in controlled cargos-targeting have been demonstrated in Table 1 [43].

Table 1. Different therapeutic applications of poly alkyl cyanoacrylate nanoparticles.

\begin{tabular}{|l|l|l|}
\hline \multicolumn{1}{|c|}{ Applications } & \multicolumn{1}{|c|}{ Materials } & \multicolumn{1}{|c|}{ Purposes } \\
\hline $\begin{array}{l}\text { Intracellular } \\
\text { targeting }\end{array}$ & $\begin{array}{l}\text { Nanoparticles with antiviral } \\
\text { or anti -parasitic cargos }\end{array}$ & $\begin{array}{l}\text { To tar get reticulo-endothelial } \\
\text { intercellul ar infections. }\end{array}$ \\
\hline Cancer therapy & $\begin{array}{l}\text { Nanoparticles with } \\
\text { oligonucleotides, anti- } \\
\text { cancer cargos }\end{array}$ & $\begin{array}{l}\text { To target cells for enhanced } \\
\text { uptake of antitum or car gos. To } \\
\text { reduce toxicity and improve in } \\
\text { vitro and in vivo stability of } \\
\text { cargos. }\end{array}$ \\
\hline Ocular therapy & $\begin{array}{l}\text { Nanoparticles with ster oi ds, } \\
\text { anti-microbial and anti- } \\
\text { inflammatory cargos for } \\
\text { glaucoma }\end{array}$ & $\begin{array}{l}\text { To improve retention of cargos } \\
\text { and to reduce wash-out. }\end{array}$ \\
\hline Other usages & $\begin{array}{l}\text { Nanoparticles with peptides } \\
\text { Copolym erized peptide } \\
\text { nanoparticles of activated } \\
\text { peptides } \\
\text { Nanoparticles with } \\
\text { radioactive or contrast agent } \\
\text { Nanoparticles with } \\
\text { adsorbed enzymes }\end{array}$ & $\begin{array}{l}\text { To cross bl ood-brain barrier, and } \\
\text { to improve absorption and } \\
\text { perm eation for transdermal } \\
\text { application. } \\
\text { To deliver peptides orally. }\end{array}$ \\
\hline
\end{tabular}

For Infectious Diseases

Generally, pathogens cause severe intracellular infections by 
developing their different survival mechanisms $[44,45]$. The entrapment of antibiotics in the nanocarriers to improve the therapeutic index by targeting drugs to infected cells have been performed [6,20,44-48], while opsonized nanoparticles containing antibiotic are entrapped in the phagolysosomal compartment through endocytosis or phagocytosis to release their bioactive ingredients into the cells [44]. The application of ampicillin entrapped poly isohexyl cyanoacrylate nanoparticles in experimental salmonellosis increased the antibiotic efficacy by 120 fold [20,49], while other antibiotics were incorporated in different PACA-based nanovehicles [44,46-48,50-54]. Ciprofloxacin entrapped PBCA nanoparticles were found active as $\mathrm{pH}$-controllable drug release against bacteria [55]. The exposure of ampicillin entrapped PIBCA nanoparticles into the infected macrophages showed their reduced viability to $99 \%$ after $30 \mathrm{~h}$ of incubation [56]. The in vivo experiment with mice showed the high efficacy of antibiotic entrapped PACA nanoparticles against intracellular infections $[44,20,56]$. The similar natures were also monitored for the applications of antiviral agents -loaded nanovehicles [57-61].

\section{For cancer}

Cancer therapy suffers from its non-selective damage especially to normal cells with additional multi-drug resistance of cells due to overexpression of P-glycoprotein. To overcome these obstacles, different bioactive compounds such as cytostatics, peptides, nucleic acids and hormones have been entrapped in PACA nanocarriers with / without PEGylation as delivery systems to target cancer cells by passive or active targeting through phagocytosis or receptor mediated endocytosis accompanied with tumorial EPR effect [6,44,62-71]. Drugs entrapped nanocarriers, thus, penetrate the leaky tumor vasculature to accumulate in the tumor interstitiums and to liberate the loaded drugs, creating their high concentrations as anticancer agents. To achieve active targeting, ligands are anchored to the surface of nanocarriers to target tumor endothelial cells that impart nutrients and oxygen to the tumor cells [72-74]. The main target specific ligands for cancer cells indicate the folate receptor, the transferring receptor, the glycoproteins and the epidermal growth factor receptors, whereas for the tumoral endothelial cells the integrins, the vascular endothelial growth factor receptors, the matrix metallo-proteinases and the vascular cell adhesion molecule-1. Recently, PACA-based nanoparticles have been functionalized to their surfaces with different targeting ligands through azide-alkyne 'click' chemistry as anticancer delivery system [74].

\section{For cerebral diseases}

A physiological blood-brain barrier may limit the transports of many bioactive compounds such as cytostatics and antibiotics to the brain tissue. This limitations may be further augmented by the BBB- related enzymes e.g. g-glutamyl transpeptidase for the degradation of the drug molecules [75]. Surface functionalized PACA NPs have shown their capabilities to deliver cargos not only into the brain but also to protect them from the enzymatic degradations [76-78,32]. In general, to target brain tissue, PACA NPs become reformed with PEG for escaping from the uptake of macrophages, or with surfactant to increase the BBBpenetrability and to obstruct $\mathrm{ABC}$ efflux protein -activity on the $\mathrm{BBB}$. Moreover, the ligand-specific nanocarriers may adsorb apolipoproteins E from blood plasma to pass through the brain endothelium through receptor mediated endocytosis and then transcytosis [78].

\section{For acquired immunodeficiency syndrome}

Human immunodeficiency virus-1 (HIV-1) causes acquired immunodeficiency syndrome (AIDS) resulting in reduction of CD4+T cells as the virus generally targets few cells such as CD4+ monocytes / macrophages, CD4+T cells, microglial cells, dendritic cells and macrophages which act as reservoir site to reproduce virus [79]. Therefore, the common strategy for combating AIDS is the killing of the HIVs in cell and tissue reservoirs. However, targeting to HIVinfected cell is not a simple issue as CD4+T cells do not persist for long time as well as lack infection markers on the infected CD4+T cells, though these cells may accumulate highly in lymph nodes. Therefore, higher therapeutic efficiency may be achieved by delivering nanocarriers loaded with anti-HIV cargos to lymph nodes for their smaller sizes suitable to be internalized by lymphocytes as well as act as intracellular cargos reservoirs [80]. In this perspect, nanocarriers may be prevented from their opsonizations by mononuclear phagocyte system by minimizing their sizes to nano range and modifying their surfaces with hydrophilic materials. Moreover, PACANPs may also be modified with the ligands of the pattern recognition receptors (PRRs) associated in the immune response for targeting cargos into the immune system, while the PRRs e.g. Toll-like receptors, C-type lectin receptors, scavenger receptors, nucleotide oligomerization domainlike receptors and retinoic acid inducible gene-like receptors can recognize few conservative elements expressed on pathogens, called pathogen-associated molecular patterns [81].

\section{Biodistribution, pharmacokinetics and elimination of poly alkyl cyanoacrylate nanoparticles}

The pharmacokinetics of drug concentration loaded in different PACA NPs formulations vary on their different routes of administration $[82,83]$. After oral administration of free and different nanoformulated drug at a single dose of $50 \mathrm{mg} / \mathrm{kg}$ body weight in rats, showed that maximum plasma concentrations of quercetin loaded PACA NPs and quercetin loaded PACA NPs coated with polysorbate80 were enhanced $\sim 1.4$ and $\sim 1.7$ folds respectively compared to free quercetin, whereas their $\mathrm{t}_{1 / 2} \mathrm{~s}$ were increased to $\sim 14 \mathrm{~h}$ and $\sim 19 \mathrm{~h}$ in comparison to $6 \mathrm{~h}$ of free quercetin. Quercetin-loaded PACA NPs and their coated-NPs showed higher concentrations of quercetin in the liver and spleen compared to free quercetin, whereas their distributions were less to the heart and kidney in comparison to free quercetin. The maximum concentration of quercetin into the brain was observed by the oral delivery of quercetin-loaded PACA NPs-coated polysorbate80 compared to the quercetin-loaded PACA NPs and free quercetin, probably owing to their receptor-mediated endocytosis through the anchorage of polysorbate- 80 for apolipoprotein-overcoated PACA NPs.

Doxorubicin (Dox) solution and Dox-loaded PACA NPs, synthesized by emulsion polymerization (EP) and dispersion polymerization (DP) techniques, were injected intraperitoneally (i.p.) into rats to study in vivo pharmacokinetics. Dox-loaded PACA NPs showed higher drug concentration in blood than Dox solution. The $\mathrm{t}_{1 / 2}$ of Dox was enhanced by DP and EP -NPs while their elimination rate constants $\left(0.2 \mathrm{~h}^{-1}\right.$ and $0.16 \mathrm{~h}^{-1}$ respectively) were lower than Dox solution $\left(0.43 \mathrm{~h}^{-1}\right)$. The area under the curve and area under moment curve of nanoparticulated Dox were significantly enhanced compared to Dox solution, while the bioavailability of Dox was augmented by DP and EP (1.9 fold and 2.12 fold respectively).

The Dox-loaded DP NPs exhibited an initial quick clearance from the blood following slow clearance after $2 \mathrm{~h}$ of intravenous (i.v.) injection to rats, while the Dox-concentration for injected DPNPs was higher than the Dox solution after $2 \mathrm{~h}$ i.v. post injection. Both DP and EP-NPs increased the $t_{1 / 2}$ and mean residence time of Dox significantly in blood rather than administered Dox solution. The area under the curve and area under moment curve were also enhanced for Dox delivered through EP and DP -NPs, while the elimination and clearance rate constant became lower compared to Dox solution. EP NPs showed the lower Dox clearance $(0.13 \mathrm{~mL} / \mathrm{min})$ in blood compared to DP NPs $(0.21 \mathrm{~mL} / \mathrm{min})$, while the area under the curve and area under moment curve became higher.

Dox solution and Dox delivered through EP and DP -NPs after i.p. injection exhibited lower drug concentration in tissue compared to after i.v. injection. After i.p. injection, Dox-distribution delivered via DP NPs was fast to liver and spleen and followed to lung after $1 \mathrm{~h}$ of administration. EP NPs, after their administration, showed lower concentration of Dox in organs of RES in comparison to DP NPs and Dox solution, while NPs showed their greatly reduced Doxdistribution to heart.

\section{Degradation and toxicity of poly alkyl cyanoacrylate nanoparticles}

The biodegradation mechanism occurs through the hydrolysis of the side chain ester bonds of the PACA NPs producing the alkyl alcohol and polycyanoacrylic acid, while the latter being water-soluble is excreted by renal filtration (Fig.3) [84-88]. This hydrolysis of PACA NPs proceeds in a couple of hours and depends on the alkyl side chain -length i.e. the longer the chain, the slower the hydrolysis catalyzed by esterases from lysosomes, plasma and pancreatic juice [89,87]. However, the full elimination of these materials may occur for PACA polymers having lower molecular weight below $10,000 \mathrm{~g} \mathrm{~mol}^{-1}$. It is also postulated that the unzipping depolymerization initiated by a base may take place in the PACA biodegradation pathway in a biological media induced by amino acid of protein followed by instant repolymerization forming lower-molecular-weight polymers [90]. 
PACA polymers may also degraded on the basis of inverse Knoevenagel condensation reaction producing alkyl cyanoacetate and formaldehyde through hydrolysis of the polymer chains having $\alpha$ hydroxyl functions if hydroxyl ions are utilized initially as an initiator [91].

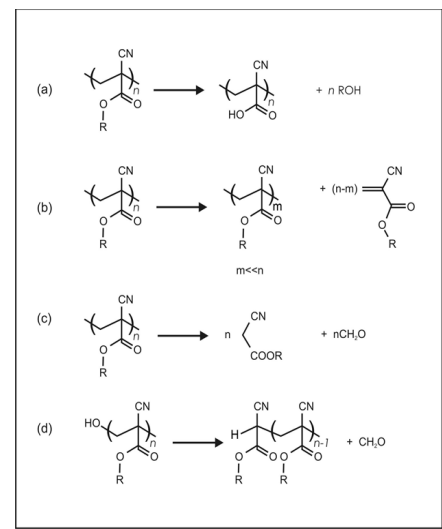

Fig.3. Possible degradation pathways of polyalkylcyanoacrylate polymers: (a) hydrolysis of ester functions, (b) unzipping depolymerization reaction, (c) the inverse Knoevenagel condensation reaction, and (d) liberation of formaldehyde from the $\alpha$-hydroxyl hydrolysis.

The cytotoxicity of PACA NPs has been correlated with the biodegradation rate of polymer backbone, while higher toxicity comes from higher biodegradation rate related to the alkyl side chain length [85]. The PACA NPs having longer alkyl chain degrade slowly and exhibit less cytotoxicity [89]. The adhesion of PACA NPs to the cell membranes may also enhance the cytotoxicity by the local liberation of higher biodegradation yields [92]. It was experimented that poly butyl cyanoacrylate NPs showed no cytotoxicity to cells at their concentration of $75 \mu \mathrm{g} / \mathrm{mL}$ whereas membrane injury appeared at their concentration of $150 \mu \mathrm{g} / \mathrm{mL}$ [93].

\section{Conclusions and future perspectives}

Conventional chemo and antimicrobial therapies have been protecting lives from infectious diseases and cancer to some extent for many decades. However, occurrences of drug resistance and new toxic agents are causing serious health-hazards. The development of new drugs and chemical modifications of existing drugs may be the approaches in combating these threats, but they may lead to limited and temporary success. In this aspect, nanotechnology based PACA NPs, due to their ease and reproducible preparation, ease of storage and administration in sterile form, suitable drug-loading capacity, sitespecificity, excellent biodegradability, low toxicity, controlled and sustained drug release capability, and feasibility for scale-up production, have attracted attention as suitable drug delivery device to overcome the biological obstacles, though the selection of specific monomers to polymerize and prepare PACA NPs is very important to get their maximum efficiency against various diseases. As PACA NPs are toxic to some extent as higher dosages, their PEGylated forms, surfactant coating and ligand binding may make them unique to be utilized for site specific drug targeting at lower dosages and to get maximum biological effectiveness.

Though PACA NPs have currently entered Phase II clinical trials expecting for the treatment of resistant cancers, this drug delivery system requires more investigations regarding their pharmacokinetics, choosing of appropriate monomers, suitable surface functionalizations with surfactants, ligands, bioactive cargos and proper polymer-coating to overcome biological barriers and polymer cytotoxicity for their specific targeting to diseased cells to get translational more efficient nanomedicines.

\section{Disclosure statement}

No potential conflict of interest was reported by the author.

\section{Acknowledgement}

This study was supported by the Council of Scientific and Industrial Research (CSIR), Government of India.

References

1. Brigger, I.; Dubernet, C.; Couvreur, P. (2002). Nanoparticles in cancer therapy and diagnosis. Adv Drug Deliv Rev, 54, 631-651. https://doi.org/10.1016/S0169$409 \mathrm{X}(02) 00044-3$

2. Hans, M.L.; Lowman, A.M. (2002). Biodegradable nanoparticles for drug delivery and targeting. Curr Opin Solid State Mater Sci, 6, 319-327. https://doi.org/10.1016/S13590286(02)00117-1

3. Panyam, J.; Labhasetwar, V. (2003). Biodegradable nanoparticles for drug and gen delivery to cells and tissue. Adv Drug Deliv Rev, 55, 329-347. https://doi.org/10.1016/S0169-409X(02)00228-4

4. Brannon-Peppas, L. (1995). Recent advances on the use of biodegradable microparticles and nanoparticles in controlled drug delivery. Int $\mathrm{J}$ Pharm, 116, 1-9. https://doi.org/10.1016/0378-5173(94)00324-X

5. Sinha, R.; Kim, G.J.; Nie, S.; Shin, D.M. (2006). Nanotechnology in cance therapeutics: Bioconjugated nanoparticles for drug delivery Mol Cancer Ther 5, 1909 1917. https://doi.org/10.1158/1535-7163.MCT-06-0141 PMid:16928810

6. Soppimath, K.S.; Aminabhavi, T.M.; Kulkarni, A.R.; Rudzinski, W.E. (2001) Biodegradable polymeric nanoparticles as drug delivery devices. J Cont Rel, 70(1-2), 120. https://doi.org/10.1016/S0168-3659(00)00339-4

7. Cabral, H.; Nishiyama, N.; Kataoka, K. (2011). Supramolecular nanodevices: From design validation to theranostic nanomedicine. Acc Chem Res, 44, 999-1008. https://doi.org/10.1021/ar200094a PMid:21755933

8. Couvreur, P.; Vauthier, C. (2006). Nanotechnology: Intelligent design to treat complex disease. Pharm Res, 23, 1417-1450. https://doi.org/10.1007/s11095-006-0284-8 PMid:16779701

9. Sukhorukov, G.B ; Rogach, A.L ; Zebli, B; Liedl, T.; Skirtach, A.G.; Kohler, K Antipov, A.A.; Gaponik, N.; Susha, A.S.; Winterhalter, M.; Parak, W.J. (2005) Nanoengineered polymer capsules: Tools for detection, controlled delivery and sitespecific manipulation. Small, 1, 194-200. https://doi.org/10.1002/smll.200400075 PMid: 17193429

10. Sperling, R.A.; Gil, P.R.; Zhang, F.; Zanella, M.; Parak WJ. (2008). Biological applications of gold nanoparticles. Chem Soc Rev, 37, 1896-1908. https://doi.org/10.1039/b712170a PMid:18762838

11. Laurent, S.; Forge, D.; Port, M.; Roch, A.; Robic, C.; VanderElst, L.; Muller, R.N. (2008). Magnetic iron oxide nanoparticles: Synthesis, stabilization, vectorization, physicochemical characterizations, and biological applications. Chem Rev, 108, 2064 2110. https://doi.org/10.1021/cr068445e PMid: 18543879

12. Kelkar, S.S.; Reineke, T.M. (2011). Theranostics: Combining imaging and therapy Bioconjugate Chem, 22, 1879-1903. https://doi.org/10.1021/bc200151 PMid:21830812

13. Mandal, A.K. (2019). Titanium dioxide nanoparticles as delivery system agains infections and cancer. Int J Curr Res, 11(1), 68-72.

14. Mandal,A.K. (2018). Vesicular drug delivery against leishmaniasis in animals: A critical evaluation. Int J Curr Res, 10(1), 64103-64113.

15. Hanahan, D.; Weinberg, R.A. (2011). Hallmarks of cancer: The next generation. Cell, 144, 646-674. https://doi.org/10.1016/j.cell.2011.02.013 PMid:21376230

16. Chabner, B.A.; Roberts, J.T.G. (2005). Timeline: Chemotherapy and the war on cancerNat Rev Cancer, 5(1), 65-72. https://doi.org/10.1038/nrc1529 PMid:15630416

17. Sahoo, S.K., Ma, V.; Labhasetwar, V. (2004). Efficacy of transferring-conjugated paclitaxel-loaded nanoparticles in a murine model of prostate cancer. Int J Cancer, 112(2), 335-340. https://doi.org/10.1002/ijc.20405 PMid:15352049

18. Wang, X.; Li, J.; Wang, Y.; Koenig, L.; Gjyrezi, A.; Giannakakou, P.; Shin, E.H.; Tighiouart, M.; Chen, Z.G.; Nie, S.; Shin, D.M. (2011). A folate receptor-targeting nanoparticle minimizes drug resistance in a human cancer model. ACS Nano, 5(8), nanoparticle minimizes drug resistance in a human cancer model. ACS Nano, 5(8),

9. Han, L.; Huang, R.; Li, J.; Liu, S.; Huang, S.; Jiang, C. (2011). Plasmid pORF-h TRAIL and doxorubicin co-delivery targeting to tumor using peptide-conjugated and doxorubicin co-delivery targeting to tumor using peptide-conjugated poly a midoam in e d e ndrimer. B i o m at, 32 (4),
https://doi.org/10.1016/j.biomaterials.2010.09.070 PMid:20971503

20. Fattal, E.; Youssef, M.; Couvreur, P.; Andremont, A. (1989). Treatment of experimental salmonellosis in mice with ampicillin-bound nanoparticles. Antimicrob Agents Chemother, 33(9), 1540-1543. https://doi.org/10.1128/AAC.33.9.1540PMid:2684009 PMCid:PMC172698

21. Barraud, L.; Merle, P.; Soma, E.; Lefrancois, L.; Guerret, S.; Chevallier, M.; Dubernet, C.; Couvreur, P.; Trepo, C.; Vitvitski, L. (2005). Increase of doxorubicin sensitivity by doxorubicin-loading into nanoparticles for hepatocellular carcinoma cells in vitro and in vivo.J Hepatol, 42,736-743, https://doi.org/10.1016/j.jhep. 2004.12.035 PMid: 15826724

22. Calvo, P.; Gouritin, B.; Villarroya, H.; Eclancher, F.; Giannavola, C.; Klein, C. Andreux, J.P.; Couvreur, P. (2002). Quantification and localization of pegylated polycyanoacrylate nanoparticles in brain and spinal cord during experimental allergic encephalomyelitis in the rat. Eur J Neurosci, 15, 1317-1326. https://doi.org/10.1046/j.1460-9568.2002.01967.x PMid:11994126

23. Reddy, L.H.; Couvreur, P. (2011). Nanotechnology for therapy and imaging of liver disease. J Hepatol, 55, 1461-1466. https://doi.org/10.1016/j.jhep.2011.05.039 PMid:21801699

24. Peracchia, M.T.; Desmaele, D.; Couvreur, P. D'Angelo, J. (1997). Synthesis of a novel poly(Me PEG cyanoacrylate-co-alkyl cyanoacrylate) amphilic copolymer for nanoparticle technology. Macromol, 30, 846-851.https://doi.org/10.1021/ma961453k

5. Calvo, P.; Gouritin, B.; Chacun, H.; Deamaele, D.; D'Angelo, J.; Noel, J.P.; Georgin, D. Fattal, E.; Andreux, J.P.; Couvreur, P. (2001). Long-circulating pegylated polycyanoacrylate nanoparticles as new drug carrier for brain delivery. Pharm Res, 18 1157-1166. https://doi.org/10.1023/A:1010931127745 PMid:11587488

26. Brigger, I.; Morizet, J.; Aubert, G.; Chacun, H.; Terrier-Lacombe, M.J.; Couvreur, P.; Vassal, G. (2002). Poly (ethylene glycol)- coated hexadecylcyanoacrylate nanospheres display a combined effect for brain tumor targeting. J Pharmacol Exp Ther, 303, 928 936. https://doi.org/10.1124/jpet.102.039669 PMid:12438511

27. Low, P.S.; Henne, W.A.; Doorneweerd, D.D. (2008). Discovery and development of folic-acid-based receptor targeting for imaging and therapy of cancer and inflammatory diseases. Acc Chem Res, 41,120-129. https://doi.org/10.1021/ar7000815 PMid: 17655275

28. Lu, Y.; Low, P.S. (2002). Folate-mediated delivery of macromolecular anticancer therapeutic agents. Adv Drug Deliv Rev, 54, 675-693. https://doi.org/10.1016/S0169409X(02)00042-X

29. Lu, Y.; Sega, E.; Leamon, C.P.; Low, P.S. (2004). Folate receptor targeted immuno therapy of cancer: Mechanism and therapeutic potential. Adv Drug Deliv Rev, 56, 1161 1176. https://doi.org/10.1016/j.addr.2004.01.009 PMid:15094213

30. Lee, E.S.; Na, K.; Bae, Y.H. (2005). Super pH-sensitive multifunctional polymeric micelle. Nano Lett, 5, 325-329 https://doi.org/10.1021/n10479987 PMid:15794620

31. Fessi, H.C.; Devissaguet, J.P. (1992). Process for the preparation of dispersible colloidal systems of a substance in the form of nanoparticles. U S Patent, $5,118,528$.

32. Gulyaev, A.E.; Gelperina, S.E.; Skidan, I.N.; Antropov, A.S.; Kivman, G.Y.; Kreuter, J. (1999). Significant transport of doxorubicin into the brain with polysorbate 80-coated nanoparticles. Pharm Res, 16(10), 1564-1569. https://doi.org/10.1023/A:1018983904537 PMid:10554098

33. Al Khoury-Fallouh, N.; Roblot-Treupel, L.; Fessi, H.; Devissaguet, J.P.; Puisieux, F. 
(1986). Development of a new process for the manufacture of poly (isobutylcyanoacrylate) nanocapsules.

34. Gasco, M.; Trotta, M. (1986). Nanoparticles from microemulsions. Int J Pharm, 29, 267 268. https://doi.org/10.1016/0378-5173(86)90125-0

35. Vranckx, H.; Demoustier, M.; Deleers, M. (1996). A new nanocapsule formulation with hydrophilic core: Application to the oral administration of salmon calcitonin in rats. Eur J Pharm Biopharm, 42, 345-347

36. Lambert, G.; Fattal, E.; Pinto-Alphandary, H.; Gulik, A.; Couvreur, P. (2000). Polyisobutyl cyanoacrylate nanocapsules containing an aqueous core as a novel colloidal carrier for the delivery of oligonucleotides. Pharm Res, 17, 707-714.

37. Watnasirichaikul, S.; Davies, N.M.; Rades, R.; Tucker, I.G. (2000). Preparation of biodegradable insulin nanocapsules from biocompatible microemulsions. Pharm Res, 17,684-689. https://doi.org/10.1023/A:1007574030674 PMid:10955841

38. Gallardo, M.M.; Couarraze, G.; Denizot, B.; Treupel, L.; Couvreur, P.; Puisieux, F. (1993). Preparation and purification of isohexylcyanoacrylate nanocapsules. Int J Pharm, 100, 55-64. https://doi.org/10.1016/0378-5173(93)90075-Q

39. Couvreur, P.; Kante, B.; Roland, M.; Guiot, P.; Bauduin, P.; Speiser, P. (1979). Polycyanoacrylate nanocapsules as potential lysosomotropic carriers: Preparation, morphological and sorptive properties. J Pharm Pharmacol, 31, 331-332. https://doi.org/10.1111/j.2042-7158.1979.tb13510.x PMid:37304

40. Lescure, F.; Zimmer, C.; Ray, D.; Couvreur, P. (1992). Optimization of polycyanoacrylate nanoparticle preparation: Influence of sulfur dioxide and $\mathrm{pH}$ on polycyanoacrylate nanoparticle preparation: Influence of sulfur dioxide and $\mathrm{pH}$ on nanoparticle characteristics. J Co
https://doi.org/10.1016/0021-9797(92) $90079-2$

41. Vauthier, C.; Couvreur, P. (2002). Degradation of poly-(alkylcyanoacrylates), in: Matsumara JP, Steinbuchel A, (Eds.). Miscellaneous biopolymers and biodegradation of synthetic polymers. Handbook of Biopolym, 9, Wiley-VHC, New York. https://doi.org/10.1002/3527600035.bpol902

42. Douglas, S.J.; Illum, L.; Davis, S.S. (1985). Particle size and size distribution of poly (butyl 2-cyanoacrylate) nanoparticles. II. Influence of stabilizers. J Colloid Interf Sci, 103,154-163. https://doi.org/10.1016/0021-9797(85)90087-6

43. Mullaicharam, A.R. (2011). Nanoparticles in drug delivery system. Int J Nutr Pharmacol Neurol Dis, 1(2), 103-109. https://doi.org/10.4103/2231-0738.84194

44. Vauthier, C.; Dubernet, C.; Fattal, E.; Pinto-Alphandary, H.; Couvreur, P. (2003). Poly (alkylcyanoacrylates) as biodegradable materials for biomedical applications. Adv Drug Deliv Rev, 55, 519-548. https://doi.org/10.1016/S0169-409X(03)00041-3

45. Pinto-Alphandary, H.; Andremont, A.; Couvreur, P. (2000). Targeted delivery of antibiotics using liposomes and nanoparticles: Research and applications. Int J Antimicrob Age, 13(3), 155-168. https://doi.org/10.1016/S0924-8579(99)00121-1

46. Kisich, K.; Gelperina, S.; Higgins, M.; Wilson, S.; Shipulo, E.; Oganesyan, E.; Heifets, L. (2007). Encapsulation of moxifloxacin within poly (butyl cyanoacrylate) nanoparticles enhances efficacy against intracellular Mycobacterium tuberculosis. Int J Pharm, 345(1-2), 154-162. https://doi.org/10.1016/j.ijpharm.2007.05.062 PMid:17624699

47. Fontana, G.; Licciardi, M.; Mansueto, S.; Schillaci, D.; Giammona, G. (2001). Amoxicillin-loaded polyethylcyanoacrylate nanoparticles: Influence of PEG coating on the particle size, drug release rate and phagocytic uptake. Biomater, 22(21), 2857-2865. https://doi.org/10.1016/S0142-9612(01)00030-8

48. Cavallaro, G.; Fresta, M.; Giammona, G.; Puglisi, G.; Villari, A. (1994). Entrapment of beta-lactams antibiotics in polyethylcyanoacrylate nanoparticles-studies on the possible in-vivo application of this colloidal delivery system. Int J Pharm, 111, 31-41. https://doi.org/10.1016/0378-5173(94)90399-9

49. Balland, O.; Pinto-Alphandary, H.; Pecquet, S.; Andremont, A.; Couvreur, P. (1994). The uptake of ampicillin-loaded nanoparticles by murine macrophages infected with Salmonella typhimurium. J Antimicrob Chemother, 33(3), 509-522. https://doi.org/10.1093/jac/33.3.509 PMid:8040115

50. Briones, E.; Colino, C.; Lanao, J. (2008). Delivery systems to increase the selectivity of antibiotics in phagocytic cells. J Cont Rel, 125(3), 210-227. https://doi.org/10.1016/j.jconrel.2007.10.027 PMid:18077047

51. Fawaz, F.; Bonini, F.; Maugein, J.; Lagueny, A. (1998). Ciprofloxacin-loaded polyisobutylcyanoacrylate nanoparticles: Pharmacokinetics and in vitro antimicrobia activity. Int J Pharm, 168, 255-259. https://doi.org/10.1016/S0378-5173(98)00116-1

52. Zhang, Q.; Liao, G.; Wei, D.; Nagai, T. (1998). Increase in gentamicin uptake by cultured mouse peritoneal macrophages and rat hepatocytes by its bioding to polybutylcyanoacrylate nanoparticles. Int J Pharm, 164, 21-27. polybutylcyanoacrylate nanoparticle
https://doi.org/10.1016/S0378-5173(97)00395-5

53. Alonso, M.; Losa, C.; Calvo, P.; Vila-Jato, J. (1991). Approaches to improve the association of amikaein sulphate to poly(alkylcyanoacrylate) nanoparticles. Int J Pharm, 68,69-76. https://doi.org/10.1016/0378-5173(91)90128-B

54. Gonzalez-Marti, G.; Figueroa, C.; Merino, L.; Osuna, A. (2000). Allopurinol encapsulated in polycyanoacrylate nanoparticles as potential lysosomatropic carrier: Preparation and trypanocidal activity. Eur J Pharm Biopharm, 49(2), 137-142. https://doi.org/10.1016/S0939-6411(99)00076-4

55. Yordanov, G.; Abrashev, N.; Dushkin, C. (2010). Poly(n-butylcyanoacrylate) submicron particles loaded with ciprofloxacin for potential treatment of bacterial infections. Prog Colloid Polym Sci, 137, 53-59. https://doi.org/10.1007/978-3-642-13461-6 11

56. Forestier, F.; Gerrier, P.; Chaumard, C.; Quero, A.; Couvreur, P.; Labarre, C. (1992). Effect of nanoparticle-bound ampicillin on the survival of Listeria monocytogenes in mouse peritoneal macrophages. J Antimicrob Chemother, 30(2), 173-179. https://doi.org/10.1093/jac/30.2.173 PMid:1399927

57. Bender, A.; Briesen, H.; Kreuter, J.; Duncan, I.; Rubsamen-Waigmann, H. (1996). Efficiency of nanoparticles as a carrier system for antiviral agents in human immunodeficiency virus-infected human monocytes / macrophages in vitro. Antimicrob Agents Chemother, 40,1467-1471. https://doi.org/10.1128/AAC.40.6.1467 PMid:8726020 PMCid:PMC163350

58. Briesen, H.; Range, P.; Kreuter, J. (2000). Controlled release of antiretroviral drugs. AIDS Rev, 2, 31-38.

59. Zhang, Z.R.; He, Q. (1999). Study on liver targeting and hepatocytes permeable valaciclovir polybutylcyanoacrylate nanoparticles. World J Gastroenterol, 5(4), 330333. https://doi.org/10.3748/wjg.v5.i4.330 PMid:11819460 PMCid:PMC4695547

60. Lobenberg, R.; Araujo, L.; Kreuter, J. (1997). Body distribution of azidothymidine bound to nanoparticles after oral administration. Eur J Pharm Biopharm, 44, 127-132. https://doi.org/10.1016/S0939-6411(97)00078-7

61. Lobenberg, R.; Araujo, L.; Briesen, H.; Rodgers, E.; Kreuter, J. (1998). Body distribution of azidothymidine bound to hexyl-cyanoacrylate nanoparticles after i.v. injection to rats. J Control Rel, 50(1-3), 21-30. https://doi.org/10.1016/S01683659(97)00105-3

62. Murthy, R.; Reddy, L. (2006). In: Amiji MM (Ed.), Nanotechnology for cancer Therapy, CRC Press.

63. Demoy, M.; Gibaud, S.; Andreux, J.; Weingarten, C.; Gouritin, B.; Couvreur, P. (1997). Splenic trapping of nanoparticles: Complementary approaches for in situ studies. Pharm Res, 14, 463-468. https://doi.org/10.1023/A:1012095431931 PMid:9144732

64. Verdun, C.; Brasseur, F.; Vranckx, H.; Couvreur, P.; Roland, M. (1990). Tissue distribution of doxorubicin associated with polyisohexylcyanoacrylate nanoparticles. Cancer Chemother Pharmacol, 26(1), 13-18. https://doi.org/10.1007/BF02940287 PMid:2322986

65. Chiannilkulchai, N.; Ammoury, N.; Caillou, B.; Devissaguet, J.; Couvreur, P. (1990). Hepatic tissue distribution of doxorubicin-loaded nanoparticles after i.v. administration in reticulosarcoma M5076 metastasis-bearing mice. Cancer Chemother Pharmacol, 26(2), 122-126. https://doi.org/10.1007/BF02897257 PMid:2189589

66. Peracchia, M.; Fattal, E.; Desmacle, D.; Besnard, M.; Noel, J.; Gomis, J.; Appel, M.; D'Angelo, J.; Couvreur, P. (1999). Stealth PEGylated polycyanoacrylate nanoparticles for intravenous administration and splenic targeting. J Control Rel, 60(1), 121-128. https://doi.org/10.1016/S0168-3659(99)00063-2

67. Gref, R.; Minamitake, Y.; Peracchia, M.; Trubetskoy, V; Torchillin, V.; Langer, R. (1994). Biodegradable long-circulating polymeric nanospheres. Science, 263(5153), 1600-1603. https://doi.org/10.1126/science.8128245 PMid:8128245

68. Bazile, D.; Prud'homme, C.; Bassoullet, M.; Marlard, M.; Spenlehauer, G.; Veillard, M. (1995). Stealth Me.PEG-PLA nanoparticles avoid uptake by the mononuclear phagocytes system. J P harm Sci, 84 (4), $493-498$ https://doi.org/10.1002/jps.2600840420 PMid:7629743

69. Treupel, L.; Poupon, M.; Couvreur, P.; Puisieux, F. (1991). Vectorisation of doxorubicin in nanospheres and reversion of pleiotropic resistance of tumor cells. C R Acad Sci III, 313(3), 171-174

70. Cuvier, C.; Roblot-Treupel, L.; Millot, J.; Lizard, G.; Chevillard, S.; Manfait, M. Couvreur, P.; Poupon, M. (1992). Doxorubicin-loaded nanospheres bypass tumor cell multidrug resistance. Biochem Pharm, 44(3), 509-517. https://doi.org/10.1016/00062952(92)90443-M

71. Bennis, S.; Chapey, C.; Couvreur, P.; Robert, J. (1994). Enhanced cytotoxicity of doxorubicin encapsulated in polyisohexylcyanoacrylate nanospheresagainst multidrugresistant tumor cells in culture. Eur J Cancer, 30(1), 89-93. https://doi.org/10.1016/S0959-8049(05)80025-5

72. Stella, B; Arpicco, S.; Peracchia, M.; Desmaele, D.; Holbeke, J; Renoir, M.; D'Angelo, J.; Cattel, L.; Couvreur, P. (2000). Design of folic acid-conjugated nanoparticles for drug targeting. J Pharm Sci, 89(11), 1452-1464. https://doi.org/10.1002/15206017(200011)89:11<1452::AID-JPS8 $>3.0$. CO;2-P

73. Duan, J.; Liu, M.; Zhang, Y.; Zhao, J.; Pan, Y.; Yang, X. (2012). Folate-decorated chitosan / doxorubicin poly(butyl)cyanoacrylate nanoparticles for tumor-targeted drug delivery. J Nanopart Res, 14, 761-769. https://doi.org/10.1007/s11051-012-0761-4

74. Nicolas, J.; Bensaid, F.; Desmaele, D.; Grogna, M.; Detrembleur, C.; Andrieux, K. Couvreur, P. (2008). Synthesis of highly functionalized poly(alkyl cyanoacrylate) nanoparticles by means of click chemistry. Macromol, 41, 8418-8428. https://doi.org/10.1021/ma8013349

5. Brasnjevic, I.; Steinbusch, H.W.; Schmitz, C.; Europe, NanoBioPharm. Res. Initiat. (2009). Delivery of peptide and protein drugs over the blood-brain barrier. Prog Neurobiol, 87(4), 212-251. https://doi.org/10.1016/j.pneurobio.2008.12.002 PMid:19395337

6. Kreuter, J. (2001). Nanoparticulate systems for brain delivery of drugs. Adv Drug Deliv Rev, 47(1), 65-81. https://doi.org/10.1016/S0169-409X(00)00122-8

77. Ramge, P.; Unger, R.; Oltrogge, J.; Zenker, D; Begley, D; Kreuter, J; Briesen, H. (2000). Polysorbate-80 coating enhances uptake of polybutylcyanoacrylate (PBCA)nanoparticles by human and bovine primary brain capillary endothelial cells. Eur J Neurosci, 12(6), 1931-1940. https://doi.org/10.1046/j.1460-9568.2000.00078.x

78. Lockman, P.R.; Mumper, R.J.; Khan, M.A.; Allen, D.D. (2002). Nanoparticle technology for drug delivery across the blood-brain barrier. Drug Dev Ind Pharm, 28(1), 1-13. https://doi.org/10.1081/DDC-120001481 PMid:11858519

79. Gunaseelan, S.; Gunaseelan, K.; Deshmukh, M.; Zhang, X.; Sinko, P.J. (2010). Surface modifications of nanocarriers for effective intracellular delivery of anti-HIV drugs. Adv Drug Deliv Rev, 62(4-5), 518-531. https://doi.org/10.1016/j.addr.2009.11.021 PMid:19941919 PMCid:PMC2841563

80. Fahmy, T.; Fong, P.; Park, J.; Constable, T.; Saltzman, W.M. (2007). Nanosystems for simultaneous imaging and drug delivery to T cells. AAPS J, 9(2), E171-180. https://doi.org/10.1208/aapsj0902019 PMid:17614359 PMCid:PMC2751406

81. Danhier, F.; Ansorena, E.; Silva, J.M.; Coco, R.; Le Breton, A.; Preat, V. (2012). PLGAbased nanoparticles: An overview of biomedical applications. J Cont Rel, 161(2),505522. https://doi.org/10.1016/j.jconrel.2012.01.043 PMid:22353619

82 Bagad, M.; Khan, Z.A. (2015). Poly (n-butyl cyanoacrylate) nanoparticles for ora delivery of quercetin: Preparation, characterization, and pharmacokinetics and biodistribution studies in Wistar rats. Int J Nanomed, 10,3921-3935. https://doi.org/10.2147/IJN.S80706 PMid:26089668 PMCid:PMC4468990

83. Reddy, L.H.; Murthy, R.S.R. (2004). Pharmacokinetics and biodistribution studies of doxorubicin loaded poly (butyl cyanoacrylate) nanoparticles synthesized by two different techniques. Biomed Papers, $148(2), 161-166$ https://doi.org/10.5507/bp.2004.029 PMid:15744366

84. Lenaerts, V.; Couvreur, P.; Christiaens-Leyh, D.; Joiris, E.; Roland, M.; Rollman, B.; Speiser, P. (1984). Degradation of poly(isobutyl cyanoacrylate) nanoparticles. Biomat, 5,65-68. https://doi.org/10.1016/0142-9612(84)90002-4

85. Lherm, C.; Muller, R.; Puisieux, F.; Couvreur, P. (1992). Alkylcyanoacrylate drug carriers: II. Cytotoxicity of cyanoacrylate nanoparticles with different alkyl chain length. Int J Pharm, 84, 13-22. https://doi.org/10.1016/0378-5173(92)90210-S

86. O'Sullivan, C.; Birkinshaw, C. (2002). Hydrolysis of poly (n-butylcyanoacrylate) nanoparticles using esterase. Polym Degrad Stabil, 78, 7-15. https://doi.org/10.1016/S0141-3910(02)00113-1

87. Scherer, D.; Robinson, J.R.; Kreuter, J. (1994). Influence of enzymes on the stability of polybutyl cyanoacrylate nanoparticles. Int J Pharm, 101, 165-168. https://doi.org/10.1016/0378-5173(94)90086-8

88. Sullivan, C.O.; Birkinshaw, C. (2004). In vitro degradation of insulin-loaded poly (nbutyl cyanoacrylate) nanoparticles. Biomat, 25,4375-4382. https://doi.org/10.1016/j.biomaterials.2003.11.001 PMid:15046928

89. Muller, R.H.; Lherm, C.; Herbort, J.; Couvreur, P. (1990). In vitro model for the degradation of alkyl cyanoacrylate nanoparticles. Biomat, 11, 590-595. https://doi.org/10.1016/0142-9612(90)90084-4

90. Ryan, B.; McCann, G. (1996). Novel sub-ceiling temperature rapid depolymerizationrepolymerization reactions of cyanoacrylate polymers. Macromol Rapid Commun, 17, 217-227. https://doi.org/10.1002/marc.1996.030170404

91. Limouzin, C.; Caviggia, A.; Ganachaud, F.; Hemery, P. (2003). Anionic polymerization of n-butyl cyanoacrylate in emulsion and miniemulsion. Macromol, 36, 667-674. https://doi.org/10.1021/ma0257402

92. Gipps, E.; Groscurth, P.; Kreuter, J.; Speiser, P. (1987). The effect of polyalkylcyanoacrylate nanoparticles on human normal and malignant mesenchyma cells in vitro. Int J Pharm, 40, 23-31. https://doi.org/10.1016/0378-5173(87)90044-5

93. Kreuter, J.; Wilson, C.G.; Fry, J.R.; Paterson, P.; Ratcliffe, J.H. (1984). Toxicity and association of polycyanoacrylate nanoparticles with hepatocytes. J Microencapsul, 1, 253-257. https://doi.org/10.3109/02652048409049364 PMid:6443850 